\title{
Congenital circumferential abdominal amniotic bands in one dizygotic twin
}

\author{
Ravibindu Ranawaka ${ }^{1}$, Chulangani Abayarathna ${ }^{2}$
}

Sri Lanka Journal of Child Health, 2015; 44(1): 64

(Key words: Congenital circumferential abdominal amniotic bands; associated anomalies)

Amniotic bands are structures composed of either acellular fibrous tissue or fibrous tissue containing fibroblasts covered by squamous cells ${ }^{1}$. Congenital circumferential abdominal amniotic bands (CCAAB) are extremely rare, and to our knowledge only eleven such cases have so far been reported in the world literature ${ }^{1,2}$. Six of these were associated with constriction of another body part. Only three had the band located inferior to the umbilicus. We report the world's first reported case of $\mathrm{CCAAB}$ in a non-identical twin whose other twin was normal.

\section{Case report}

The second of non-identical twins was a girl weighing $1.8 \mathrm{~kg}$ with a CCAAB. She was born by caesarean section to a primigravida with gestational diabetes. She had no associated congenital anomalies. Her twin sister weighed $2.2 \mathrm{~kg}$ and was normal. The constricting amniotic band encircled the abdomen indenting skin above the level of the anterior superior iliac spine (Figures 1 and 2).



Figure 1: CCAAB band - Front view

${ }^{1}$ Consultant Paediatric Surgeon, ${ }^{2}$ Medical Officer, Sirimavo Bandaranayake Specialised Children's Hospital, Peradeniya

(Received on 26 December 2013: Accepted after revision on 24 January 2014)



Figure 2: CCAAB band - Back view

The ultrasound scan confirmed that the extension of CCAAB was limited to the skin and subcutaneous tissue. Intra-abdominal viscera were normal. The echocardiogram was normal. The CCAAB was surgically excised because the degree of constriction would impair abdominal wall growth, The anterior aspect of the band and the ischaemic fibrotic dermal tissue were excised first, on the seventh day of life. The skin was closed with subcuticular polydioxy-xenon sutures. One week afterwards, the posterior part was excised. Histology of excised tissue showed fibrous tissue only. On review after three months the scars had healed and she was well.

\section{References}

1. Kim JB, Berry MG, Watson JS. Abdominal constriction band: A rare location for amniotic band syndrome. Journal of Plastic, Reconstructive \& Aesthetic Surgery 2007; 60(11): 1241-3.

http://dx.doi.org/10.1016/j.bjps.2006.10.015

2. Gargh K, Sullivan C, Laing H, Banerjee S. Congenital circumferential constriction band of the abdomen: A case report. Case Reports in Medicine 2009; Article ID 825174, 3 pages. Available from: http://dx.doi.org/10.1155/2009/825174 